\title{
Aktivitas Antioksidan Minyak Atsiri dan Ekstrak Etanol Kulit Batang Sintok (Cinnamomum sintoc Bl.) terhadap 1,1-difenil-2- pikrilhidrazil (DPPH)
}

\section{Antioxidant Activity of Sintoc (Cinnamomum sintoc Bl.) Essential Oil and the Ethanol Extract of Its Bark by Using 1,1-Diphenyl-2- Picrylhidrazyl (DPPH)}

\author{
Sri Adi Sumiwi ${ }^{1}$, Anas Subarnas ${ }^{1}$, Supriyatna $^{1}$, dan Marline $\mathbf{A}^{\mathbf{1}}$ \\ ${ }^{1}$ Fakultas Farmasi Universitas Padjadjaran, Jatinangor - Sumedang
}

\begin{abstract}
ABSTRAK
Sintok (Cinnamomum sintoc Bl.) merupakan tumbuhan yang dapat digunakan untuk pengobatan. Tumbuhan ini telah diketahui memiliki aktivitas analgesik antiinflamasi yang kemudian diduga juga memiliki aktivitas antioksidan. Telah dilakukan penelitian mengenai aktivitas antioksidan dengan berbagai konsentrasi minyak atsiri dan ekstrak etanol kulit batang sintok dengan pembanding vitamin C. Minyak atsiri dan ekstrak etanol kulit batang sintok diuji terhadap senyawa DPPH (1,1-difenil-2pikril-hidrazil) dengan mengukur absorbansi menggunakan spektrofotometer sinar tampak pada panjang gelombang $518 \mathrm{~nm}$. Metode penelitian yang dilakukan meliputi destilasi minyak atsiri dan ekstraksi kulit batang sintok, penetapan $\mathrm{IC}_{50}$ minyak atsiri dan ekstrak etanol dengan pembanding vitamin C. Variasi konsentrasi sampel uji yang digunakan pada pengujian ini adalah $15 ; 5 ; 1 ; 0,1 ; 0,5$ ppm untuk minyak atsiri dan $25 ; 20 ; 17 ; 15 ; 10$ ppm untuk ekstrak. Hasil penelitian menunjukkan bahwa minyak atsiri kulit batang sintok memiliki aktivitas antioksidan dengan nilai $\mathrm{IC}_{50}$ sebesar 16,29 ppm (5 kali lebih lemah dibandingkan vitamin C), sedangkan ekstrak etanol nilai $\mathrm{IC}_{50}$ sebesar 38,89 ppm (11 kali lebih lemah dibandingkan vitamin $\mathrm{C}$, dimana $\mathrm{IC}_{50}$ vitamin $\mathrm{C}$ adalah $\left.3,35 \mathrm{ppm}\right)$.
\end{abstract}

Kata kunci : Antioksidan, Cinnamomum sintoc Bl., DPPH

\begin{abstract}
Sintoc (Cinnamomum sintoc Bl.) is a plant which is used as medicine. This plant has been known to have an analgesic antiinflamatory activity, therefore it is predicted to have an antioxidant activity. An investigation on antioxidant activity of sintoc essential oils and ethanolic extract of its cortex using ascorbic acid as standard has been carried out. Essential oils and ethanol extract of sintoc cortex was tested using DPPH (1,1-diphenyl-2-pikril-hidrazil) by measuring absorbance using visible spectrophotometer at $518 \mathrm{~nm}$. The methods of this research were distillation of essential oils and extraction of sintoc cortex, determination of the essential oil and extract concentrations required for $50 \%$ inhibition of DPPH radical scavenging effect $\left(I C_{50}\right)$ with ascorbic acid as the possitive control. The variation concentration of essential oils are 15, 5, 1, 0.1, $0.5 \mathrm{ppm}$ and 25, 20,17, 15, $10 \mathrm{ppm}$ for ethanolic extracts. The results showed that the essential oil showed antioxidant activity with $I_{50}$ value was 16.29 ppm (5 times lower than ascorbic acid) and then ethanolic extract showed $I_{50}$ value 38.89 ppm (11 times lower than ascorbic acid, IC 50 of ascorbic acid was 3.35 ppm).
\end{abstract}

Keyword : Antioxidant, Cinnamomum sintoc B1., DPPH 


\section{Pendahuluan}

Dewasa ini penggunaan senyawa antioksidan kian berkembang, baik untuk makanan maupun pengobatan. Penggunaan antioksidan sebagai obat terus dikembangkan seiring dengan makin bertambahnya pengetahuan tentang aktivitas radikal bebas yang dapat menimbulkan kerusakan sel dan mendasari berbagai macam keadaan patologik. (Boer, 2000).

Antioksidan merupakan suatu
senyawa yang memperlambat atau
mencegah proses oksidasi dengan cara menghentikan reaksi berantai dari radikal bebas. Dengan demikian radikal bebas tidak berikatan dengan senyawa lain untuk menjadi stabil. Radikal bebas dalam jumlah berlebih di dalam tubuh sangat berbahaya karena menyebabkan kerusakan sel, asam nukleat, protein dan jaringan lemak. Peranan antioksidan sangat penting dalam menetralkan dan menghancurkan radikal bebas. (Hernani, 2005)

Antioksidan dikelompokkan menjadi dua kelompok, yaitu antioksidan sintetik (antioksidan yang diperoleh dari hasil sintesa reaksi kimia) dan antioksidan alami (antioksidan hasil ekstraksi bahan alami).

Antioksidan alami banyak berasal dari tumbuhan dan senyawa ini tersebar pada beberapa bagian tumbuhan, seperti akar, batang, kulit, daun, bunga, buah, dan biji. Antioksidan alami berfungsi sebagai reduktor, penekan oksigen singlet, pemerangkap radikal bebas dan sebagai pengkhelat logam. Antioksidan tersebut meliputi golongan senyawa turunan fenolat seperti flavonoid, turunan senyawa hidroksinat, kumarin, tokoferol, dan asam bermartabat banyak. Antioksidan ini dapat berasal dari senyawa antioksidan yang sudah ada dari satu atau dua komponen makanan, senyawa antioksidan yang terbentuk dari reaksi-reaksi selama proses pengolahan ataupun senyawa antioksidan yang diisolasi dari sumber alami dan ditambahkan ke makanan sebagai bahan tambahan pangan (Kumalaningsih, 2006).

Berdasarkan mekanisme kerjanya, antioksidan dapat dikelompokkan menjadi tiga kelompok, yaitu:

Antioksidan primer (antioksidan endogen atau antioksidan enzimatis), contohnya enzim peroksidase dismutase, katalase dan glutation peroksidase. Enzim-enzim ini mampu menekan atau menghambat pembentukan radikal bebas dengan cara memutus reaksi berantai dan mengubahnya menjadi produk stabil. Reaksi ini disebut sebagi chain-breaking-antioxidant.

Antioksidan sekunder (antioksidan eksogen atau antioksidan non enzimatis). Contoh antioksidan sekunder ialah vitamin $\mathrm{E}$, vitamin $\mathrm{C}, \beta$-karoten, isoflavon, asam urat, bilirubin dan albumin. Senyawasenyawa ini dikenal sebagai penangkap radikal bebas (scavenger free radical), kemudian mencegah amplifikasi radikal.

Antioksidan tersier, misalnya enzim DNArepair, metionin sulfoksida reduktase, yang berperan dalam perbaikan biomolekul yang disebabkan oleh radikal bebas (Prakash, 2001).

Sistem defensif yang dimiliki setiap sel untuk menghadapi radikal bebas yang telah disebutkan diatas dapat menimbulkan berbagai penyakit adalah berupa antioksidan enzimatis yang pertama kali ditemukan oleh J.M Mc Cord dan I.Fridovich (Ilmuwan Amerika pada tahun 1968) yang menemukan enzim antioksidan alami pada tubuh manusia dengan nama SOD. Antioksidan enzimatis lainnya adalah glutation, katalase, thioredoxin reduktase, heme oksigenase, biliverdin reduktase dan ubiquinol (Suprapto, 2003).

Antioksidan yang didapat dari luar tubuh misalnya alfa tokoferol akan mencegah peroksidasi lipid dengan memaksa peroksi lipid. Tokoferol akan 
mentransfer atom hidrogen (dengan elektron tunggalnya). Jadi menghilangkan radikal bebas peroksil, lebih cepat dari radikal bebas peroksil, lebih cepat dari reaksi radikal ini dengan protein membrane atau dengan rantai samping asam lemak, asam lemak tak jenuh (PUFA).

$$
\text { Lipid-O2 }{ }^{\circ}+\text { tokoferol-OH } \rightarrow
$$

Lipid-O2H + Tokoferol-O ${ }^{\circ}$

Radikal tokoferol (tidak reaktif) akan dihilangkan oleh vitamin $\mathrm{C}$ (askorbat) :

Tokoferol-O ${ }^{\circ}+$ Askorbat $\rightarrow$

Lipid-OH + semidehidroksiaskorbat

Jadi fungsi vitamin $\mathrm{C}$ disini adalah untuk mendaur ulang tokoferol. Sedangkan semihidroaskorbat akan dikembalikan menjadi askorbat oleh enzim NADH atau glutation tereduksi (GSH).

$\mathrm{GSH}+$ Askorbat $\rightarrow$ GS +

Askorbat $\mathrm{H}^{-}$

Bentuk radikal glutation reduktase dapat saling menetralkan satu sama lain membentuk glutation peroksidase (GSSG).

$$
\begin{array}{llll}
\mathrm{GH} & \mathrm{GH} & \rightarrow & \mathrm{GSSG} \\
\text { (Wijaya,1996). } & & &
\end{array}
$$

Tanaman sintok (Cinnamomum sintoc B1.) dapat digunakan sebagai obat luar maupun dalam. Bagian yang dapat digunakan sebagai obat adalah kulit batang, kulit cabang dan daun. Dari beberapa penelitian ilmiah yang telah dilakukan, minyak atsiri dari kulit batang sintok memiliki aktivitas sebagai analgesik dan antiinflamasi. Inflamasi merupakan respons protektif yang ditimbulkan oleh cedera atau kerusakan sel atau jaringan yang berfungsi menghancurkan, mengurangi, atau mengurung (sekuestrasi) baik agen pencedera maupun jaringan yang cedera itu. Disamping itu radikal bebas juga dapat menggangu keutuhan sel atau jaringan, karena dapat bereaksi dengan komponen sel tersebut sehingga terjadi kerusakan . Telah diketahui bahwa batang kulit sintok bisa digunakan untuk mencegah pembengkakkan (inflamasi), dimana yang seharusnya sel-sel kulit tersebut terpapar oleh radikal bebas atau rusak teroksidasi, tetapi bisa dihambat oleh aktivitas dari kulit batang sintok (Heyne, 1987). Dari hal tersebut dicurigai bahwa batang kulit sintok juga memiliki aktivitas antioksidan.

Metode yang digunakan dalam pengujian aktivitas antioksidan umumnya adalah metode serapan radikal 1,1Diphenyl-2-Picrylhidrazyl (DPPH), karena merupakan metode yang sederhana, mudah, dan menggunakan sampel dalam jumlah yang sedikit dengan waktu yang singkat (Sunardi, 2007). Pengukuran aktivitas antioksidan sampel dilakukan pada panjang gelombang maksimum DPPH, dengan konsentrasi tertentu. Adanya aktivitas antioksidan dari sampel mengakibatkan perubahan warna pada larutan DPPH dalam pelarut yang semula berwarna violet pekat menjadi kuning pucat (Hanani, 2005).

Dari latar belakang tersebut, maka pada dilakukan penelitian mengenai aktivitas antioksidan dari minyak atsiri dan ekstrak etanol kulit batang sintok.

\section{Metode}

Alat: Alat-alat yang digunakan pada penelitian ini adalah maserator, rotary evaporator, beaker glass, cawan penguap, penangas air, timbangan analitik, mortar dan stamper, sonifikator, stopwatch, spektroskopi UV Visible Specord 200 Analytik Jena, dan alat-alat yang lazim digunakan di laboratorium fitokimia dan laboratorium Penelitian.

\section{Bahan}

Bahan tumbuhan:Kulit batang sintok (Cinnamomum sintoc B1.) yang digunakan dalam penelitian didapat dari kebun percobaan tanaman obat Manoko, Lembang. Simplisia di determinasi di Laboratorium Taksonomi Tumbuhan, 
Jurusan Biologi, Fakultas Matematika dan Ilmu Pengetahuan Alam Universitas Padjadjaran Jatinangor.

Bahan Kimia: Uji aktivitas antioksidan menggunakan senyawa DPPH (1,1diphenyl-2-picrylhydrazyl), aquadest, vitamin $\mathrm{C}$, pelarut etanol $70 \%$, pelarut etanol $96 \%$.

\section{Tahap Penelitian}

\section{Pengumpulan Bahan dan Determinasi Tanaman :}

Bahan tanaman yang digunakan adalah batang kulit sintok (Cinnamomum sintoc B1.) yang didapat di daerah Lembang. Bahan dideterminasi di Laboratorium Taksonomi Tumbuhan, Jurusan Biologi, Fakultas MIPA, Universitas Padjadjaran.

\section{Isolasi Minyak Atsiri Kulit Batang Sintok dengan Metode Destilasi Uap: Batang kulit sintok yang sudah dikeringkan dan di tumbuk halus sebanyak kurang lebih $2 \mathrm{~kg}$, kemudian mengalami proses destilasi dengan metode destilasi uap air (water and steam distillation) selama 8 jam dengan pelarut aquadest kemudian destilat yang diperoleh dikumpulkan dan dihitung nilai rendemennya.}

\section{Ekstraksi Kulit Batang Sintok dengan Cara Maserasi :}

Batang kulit sintok yang sudah kering ditimbang sebanyak 800 gram. Bahan tersebut di ekstraksi secara maserasi dengan menggunakan pelarut etanol sebanyak $3 \times 1$ liter selama $3 \times 24$ jam. Ekstraknya ditampung dan dipekatkan dengan vacuum rotary evaporator kemudian ekstrak pekat yang didapat diuapkan dengan waterbath. Diperoleh ekstrak kental lalu ditimbang.

\section{Penetapan $\mathrm{IC}_{50}$}

Penetapan $\mathrm{IC}_{50}$ dilakukan terhadap senyawa DPPH ( 1,1 - diphenyl - 2 - picrylhydrazyl ) dengan prosedur sebagai berikut:

1. Pembuatan larutan uji : Dibuat larutan uji dalam berbagai konsentrasi dalam pelarut etanol $96 \%$. Timbang $10 \mathrm{mg}$ minyak atsiri serta ekstrak dan larutkan hingga $100 \mathrm{ml}$ dengan pelarut etanol, didapat larutan awal untuk pengenceran larutan uji $100 \mathrm{ppm}$. Kemudian dibuat pengenceran dengan variasi konsentrasi 1,5 x $10^{-3}, 0,5 \times 10^{-3}, 0,1 \times 10^{-3}, 0,1 \times 10^{-4}, 0,5$ x $10^{-5}$ untuk minyak atsiri dan $25,20,17$, 15, 10 untuk ekstrak. Sedangkan untuk vitamin $\mathrm{C}$ dibuat pengenceran dengan variasi konsentrasi 2, 4, 6, 8, dan $10 \mathrm{ppm}$.

2. Pembuatan larutan DPPH : DPPH sebanyak $4 \mathrm{mg}$ dilarutkan dalam etanol $96 \%$ sampai $100 \mathrm{ml}$ sehingga didapat larutan $0,004 \%$ (40 ppm). Larutan dijaga pada suhu rendah, terlindung dari cahaya untuk segera digunakan.

3. Penetapan $\lambda$ maksimum dan absorbansi blanko DPPH : Larutan DPPH ditambahkan dengan etanol $96 \%$, dengan perbandingan $3: 2$, blanko digunakan etanol $96 \%$ dihomogenkan dan diamati absorbansinya pada rentang $\lambda 518 \mathrm{~nm}$ dan dilihat absorbansinya.

4. Pengukuran $\%$ inhibisi minyak atsiri serta ekstrak etanol kulit batang sintok: Masing-masing larutan uji (2 ml) minyak atsiri dan ekstrak etanol kulit batang sintok dengan berbagai konsentrasi ditambahkan dengan larutan DPPH (3 ml), dihomogenkan, diinkubasi selama 30 menit kemudian diukur absorbansinya.

5. Pengukuran $\mathrm{IC}_{50}$ : Harga $\mathrm{IC}_{50}$ dihitung dari kurva regresi linier antara \% penghambatan serapan dengan berbagai konsentrasi ekstrak (larutan uji). Pengukuran $\mathrm{IC}_{50}$ dilakukan dengan menggunakan rumus:

$$
\% \text { inhibisi }=1-\frac{\text { A hitung }}{\text { ADPPH }} \times 100 \%
$$




\section{Hasil dan Pembahasan \\ Destilasi Uap}

Proses destilasi simplisia kering dilakukan dengan metode destilasi uap air (water and steam distillation) selama 8 jam dengan pelarut aquadest kemudian destilat dikumpulkan. Destilasi $2 \mathrm{~kg}$ kulit batang kering sintok didapatkan minyak atsiri yang berbentuk cair, berwarna kuning kehijauan, dan mempunyai bau dan rasa khas sebanyak $10 \mathrm{ml}$ dengan rendemen sebesar $0,5 \% \mathrm{v} / \mathrm{b}$.

Tabel 1. Sifat Fisik Minyak Atsiri Kulit Batang Sintok

\begin{tabular}{ll}
\hline Sifat Fisik & Minyak Atsiri \\
Pemeriksaan Organoleptis & Kulit Batang Sintok \\
\hline Bentuk & Cair \\
Warna & Kuning kehijauan \\
Bau & Menyengat \\
Rasa & Pedas \\
\hline
\end{tabular}

\section{Ekstraksi}

Hasil ekstraksi kulit batang sintok $(800,34 \mathrm{~g})$ dengan cara maserasi dengan etanol $70 \%$ sebanyak $5392 \mathrm{ml}$, diperoleh ekstrak kental 116,29 g dan rendemen ekstrak sebesar $14,53 \%$ dengan karakteristik bentuk kental, warna coklat kemerahan, bau khas dan rasa pahit.

\begin{tabular}{llll}
\cline { 2 - 3 } Tabel 2. & Pemerian & Ekstrak Kulit Batang Sintok & Sifat Fisik \\
Ekstrak & Bentuk & Kental & Kulit \\
& Warna & Coklat kemerahan & \\
& Bau & Khas & \\
& Rasa & Pahit &
\end{tabular}

Penetapan IC $_{50}$ dari Minyak Atsiri dan Ekstrak Etanol Kulit Batang Sintok : DPPH memberikan absorpsi maksimum pada panjang gelombang $518 \mathrm{~nm}$. Nilai IC50 minyak atsiri dan ekstrak etanol kulit batang sintok berturut-turut adalah 16,29 ppm (5 kali lebih lemah dibandingkan vitamin C), dan 38,89 ppm (11 kali lebih lemah dibandingkan vitamin C), sedangkan nilai $\mathrm{IC}_{50}$ vitamin $\mathrm{C}$ adalah $3,35 \mathrm{ppm}$. Kurva regresi linier untuk penetapan $\mathrm{IC}_{50}$ minyak atsiri serta ekstrak etanol dan vitamin $\mathrm{C}$ dapat dilihat pada Gambar 1, Gambar 2 dan Gambar 3. 


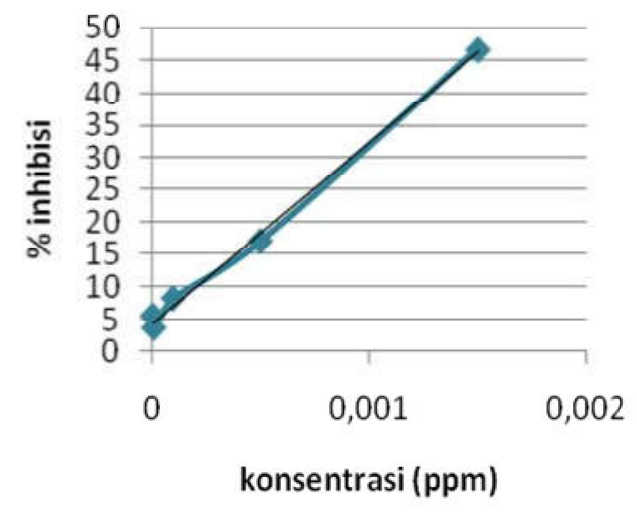

$y=27991 x+4,381$

$R^{2}=0,996$

Gambar 1 Kurva regresi linier untuk penetapan $\mathrm{IC}_{50}$ minyak atsiri kulit batang sintok

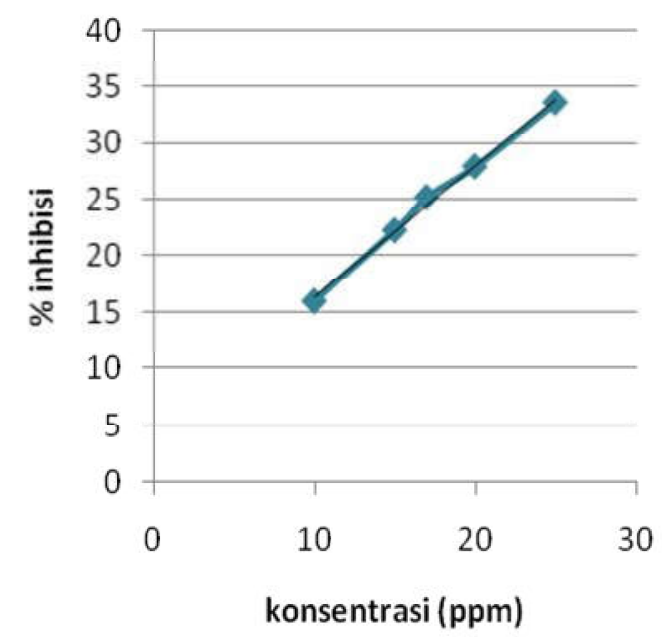

$y=1,164 x+4,730$ $R^{2}=0,995$

Gambar 2 Kurva regresi linier untuk penetapan $\mathrm{IC}_{50}$ ekstrak etanol kulit batang sintok

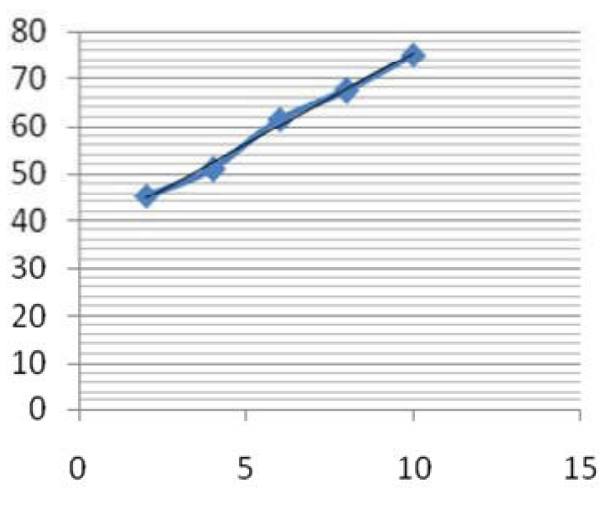

Gambar 3 Kurva regresi linier untuk penetapan $\mathrm{IC}_{50}$ vitamin $\mathrm{C}$ 


\section{Simpulan}

Minyak atsiri dan ekstrak etanol kulit batang sintok (Cinnamomum sintoc B1.) memiliki aktivitas antioksidan, sehingga berpotensi untuk digunakan sebagai penangkap radikal bebas di dalam tubuh.

\section{Pustaka}

Boer, Y. 2000. Uji Aktivitas Antioksidan Ekstrak Kulit Buah Kandis (Garcinia parvifolia Miq), Jurnal Matematika dan IPA 1. Hal. 26.Kikuzaki, H., Hisamoto, M., Hirose,K., Akiyama, K., and Taniguchi, H., 2002; Antioxidants Properties of Ferulic Acid and Its Related Compound, J.Agric.Food Chem, 50:2161-2168.

Hanani, E, A. Mun'im, R. Sekarini, 2005. Identifikasi Senyawa Antioksdian Dalam Spons Callyspongia sp Dari Kepulauan Seribu. Majalah Ilmu Kefarmasian, Vol II, No 3 (2005). Hal. 127-133.

Heyne, K. 1987. Tumbuhan Berguna Indonesia II. Balai Penelitian dan Pengembangan Kehutanan Departemen Kehutanan: Jakarta. Hal. 805-806
Jantan, I., Mira F.Y., Ayop N., and Abu Said A. 2005. Constituents of The Essential Oils of Cinnamomum sintoc Blum from Mountain Forest of Peninsula Malaysia, Flavor and Fragrance Journal, vol 20,no. 6, pp. 601-604.

Parwata, I. M., Oka A., Susanah R. W. 2009. Isolasi dan Uji Antiradikal Bebas Minyak Atsiri pada Daun Sirih (Piper betle Linn.) secara Spektroskopi Ultra Violet-Tampak, Jurnal Kimia 3(1), pp. 7-13

Sunardi, Ilham. 2007. Uji Aktivitas Antioksidan Ekstrak Belimbing Wuluh (Averrhoa bilimbi, L.) terhadap 1,1 -dipheny l-2picrylhidrazyl (DPPH). Seminar Nasional Teknologi Yogyakarta: DIII Teknologi Farmasi Fakultas Tehnik Universitas Setia Budi. 